\title{
THE CONTRIBUTION TO PROTECTING THE AQUATIC ENVIRONMENT IN OPEN-PIT AGGREGATE MINES USING REMOTE-CONTROLLED BATHYMETRY
}

\author{
Krakowskie Zakłady Eksploatacji Kruszywa S.A.
}

Keywords: shore stability, dredging machine, benthic vegetation, bottom segmentation, mining reclamation, natural resources management, safe extraction

\footnotetext{
Abstract

The opencast extraction of aggregates (sand and gravel) affects the change in landscape, including the formation of anthropogenic water reservoirs. The research were conducted in selected open-pits mines in southern Poland. In the research, a remote-controlled bathymetric device, constructed by the author, was used. Firstly, the investigation aimed to check the method under strictly defined conditions in open-pit mines of aggregates. But, above all, the study cycle aimed to verify whether a remote-controlled bathymetry could successfully be helpful for protecting the aquatic environment. The following issues were discussed in the paper:

- characteristics of the applied remote-controlled bathymetric set Smart-Sonar-Boat,

- characteristics of the obtained bathymetric data,

- research that were conducted by the author on aquatic environment of open pit mines by applying remotely controlled bathymetric measurements,

- what contribution to the aquatic environment of open pit mines could be made using such measurements.

The research were conducted in southern Poland in the following facilities:

- Zator-Podolsze Nowe Aggregate Mine, where the colonies of night heron birds (Nycticorax nycticorax) nested on the island,

- Dwory Aggregate Mine in the city of Oświęcim, where the aggregates were being extracted in close vicinity to high voltage electricity lines and railway tracks,

- Brzegi Aggregate Mine in the city of Kraków, where the reclamation works were being performed to develop the post-mining area into the water park of Przystań Brzegi,

- Lake of Bagry Wielkie in the city of Kraków where the research of a hard-to-reach water area was conducted.

The study proved the applied remote-controlled bathymetric method was practical, effective and accurate in open-cast aggregate mines. The research confirmed the contribution to protecting the aquatic environment could be made using remotely controlled geodetic measurements. The completed research stages were described in detail in separate articles. The detailed results of the planned tasks will be published after their completion.
}

\section{ZASTOSOWANIE ZDALNEJ BATYMETRII JAKO WKLAD DO OCHRONY ŚRODOWISKA WODNEGO W KOPALNIACH ODKRYWKOWYCH}

Słowa kluczowe: stateczność zboczy eksploatacyjnych, podwodna eksploatacja, roślinność denna, struktura dna zbiornika wodnego, rekultywacja, zarządzanie zasobami naturalnymi, bezpieczna eksploatacja

\footnotetext{
Abstrakt

Odkrywkowa eksploatacja kruszyw naturalnych (piasku i żwiru) niesie ze sobą zmiany w krajobrazie, przyczyniając się również do powstawania antropogenicznych zbiorników wodnych. Badania zostały przeprowadzone w wybranych kopalniach kruszyw
} 
w południowej Polsce z zastosowaniem autorskiego. zdalnie sterowanego urządzenia batymetrycznego Smart-Sonar-Boat. Pierwszym celem badań była weryfikacja metody pomiarowej w ściśle określonych warunkach, jakie występowały w kopalniach odkrywkowych kruszyw naturalnych. Cykl badań miał przede wszystkim na celu sprawdzenie, w jakim stopniu zdalna batymetria mogła być pomocna do ochrony środowiska wodnego. W artykule poruszono następujące kwestie:

- charakterystyka zastosowanego zdalnego zestawu batymetrycznego Smart-Sonar-Boat,

- charakterystyka uzyskanych danych batymetrycznych,

- badania batymetryczne przy zastosowaniu zdalnie sterowanego zestawu batymetrycznego, jakie zostały przeprowadzone przez autora w kopalniach odkrywkowych,

- wkład, jaki może być wniesiony w wiedzę o środowisku wodnym w kopalniach odkrywkowych stosując tego typu obserwacje.

Pomiary badawcze przeprowadzono w południowej Polsce w następujących obiektach:

- Kopalnia Kruszywa „Zator - Podolsze-Nowe” w miejscowości Zator, gdzie gniazdowały rzadko występujące kolonie ślepowronów (Nycticorax nycticorax),

- Kopalnia Kruszywa „Dwory” w Oświęcimiu, w której prowadzono eksploatację surowca w bliskim sąsiedztwie linii wysokiego napięcia oraz linii kolejowej,

- Kopalnia Kruszywa „Brzegi” w Krakowie, gdzie prowadzone były prace rekultywacyjne dla zagospodarowania terenu poeksploatacyjnego w celu utworzenia obiektu rekreacyjnego „Przystań Brzegi”,

- Otwarty zbiornik rekreacyjny Bagry Wielkie w Krakowie, gdzie wykonane zostały pomiary badawcze trudnodostępnego obszaru wodnego.

Wyniki wykazały, że zastosowana metoda zdalnej batymetrii była w kopalniach odkrywkowych praktyczna, skuteczna i dokładna. Badania potwierdziły możliwość znacznego wkładu takich obserwacji w ochronę środowiska wodnego. Poszczególne etapy badań zostały szeroko opisane w osobnych artykułach. Szczegółowe wyniki planowanych zadań zostaną opisane po zakończeniu obserwacji.

\section{INTRODUCTION}

Nowadays, the anthropogenic impact on landscape is considered more and more invasive, including also the environmental impact of open-cast mining operation. Therefore, the process of reclamation of post-mining areas is crucial for maintaining the balance in the environment. On the other hand, the natural aggregates - sand and gravel - are essential resources for use in construction. When they are extracting, it is likely that a reservoir, filled up with surface water, is being formed. The integration of geodetic and bathymetric technologies enabled to conduct effective and accurate measurements of the bottom of reservoirs, what can be helpful in management of aquatic environment after the mining works are completed (Madusiok and Maciaszek, 2014; Ochałek et al., 2018). For this purpose, a remote controlled device, based on the USV methodology (unmanned surface vehicle), was designed by the author, and named as Smart-Sonar-Boat. In the paper, the technical specification of the instrument was characterized, the obtained bathymetric data were described, and the author's bathymetric research were presented. The article also indicated the potential contribution that could be made to protecting the aquatic environment with application of remotely controlled bathymetric measurements.

\section{TECHNICAL SPECIFICATION OF SMART-SONAR-BOAT}

The Smart-Sonar-Boat is a remote-controlled device (boat) used for bathymetric measurement. The body of the boat $-55 \mathrm{~cm}$ wide, $78 \mathrm{~cm}$ long and $24 \mathrm{~cm}$ high is designed to be equipped with two removable sonar systems and a complete GPS receiver (fig. 4). In the presented research the Lowrance Mark-4 echosounder, with a frequency of $200 \mathrm{kHz}$ and a beam angle of $60^{\circ}$, was applied. The space for two sonar systems was intended for simultaneous measurements with more than one frequency. The application of the lower frequency of $50 \mathrm{kHz}$ and the higher one of $200 \mathrm{kHz}$ at the same time of measurement enable us to assess the sediment layer of the bottom (Sessarego, Guillermin and Ivakin, 2008). To record the bathymetric path, the sonar depths were pared with the GPS coordinates. The obtained data - geographical coordinates and depths - 
were transmitted wirelessly and in real time to the control panel. The transmission was conducted with the NMEA protocol (National Marine Electronics Association), using a simple ASCII code. The data were also being stored in the memory of the echosounder with an extension of *.s12 file. The positioning was obtained with the EGNOS satellite augmentation-based system of an accuracy between 1 and 2 meters, which was high enough in most cases. To increase the accuracy of the position, the precise GNSS (Global Navigation Satellite System) was applied, e.g. the research on the Lake of Bagry Wielkie (Gawałkiewicz and Madusiok, 2018b). The electric motors of the boat were powered by two $6 \mathrm{~V}$ gel batteries, connected in series to double the voltage and reach the speed up to $3 \mathrm{~m} / \mathrm{s}$.

\section{BATHYMETRIC DATA}

The bathymetric measurement, based on acoustics, allow us to obtain the following data: depths of water, characteristics of the bottom like its hardness (Kloser et al., 2001; Kozioł et al., 2013) or distribution of benthic vegetation (Brown and Blondel, 2009). In the research, the measurement of depths was based on knowing the speed of the sound wave in aquatic environment. To assign position values with depth values, the bathymetric measurements was integrated with the GPS receiver. To determine the depth of the reservoir, an acoustic signal was sent towards the bottom surface, then, after being reflected, it was received by a transducer. The analysis of depth values, which were spread over the entire study area and the application of specialized interpolation methods such as kriging (Lenda et al., 2015) could be useful for assessing the risk of underwater landslides in mining water environment.

During the extraction of aggregates below the water table, the shape and structure of reservoirs were constantly changing. To study the composition characteristics of the bottom of water-bodies, the energy of reflected acoustic beam was analyzed. The following physical dependence was used: the harder the obstacle, the higher the reflected energy of the signal; accordingly, the softer the bottom composition, the lower the echo-energy (Orłowski, 1984; Bunchuk and Ivakin, 1989). The application of an automated composition algorithm enabled to determine the hardness of the bottom according to relative and continuous scale of reflected sound energy in the range from 0 to 0.5 (Valley, 2014). The low values $(0 \div 0.2)$ could indicate a loosely mixed structure, such as silted material or fine sand; those within the medium section $(0.2 \div 0.4)$ could indicate a loamy structure; and the hardest values $(0.4 \div 0.5)$ could indicate compacted clay material or large compacted stones.

The acoustic technique also enabled studying distribution of aquatic plants (Madusiok, 2016b). At the beginning of formation of the mining open-water reservoir, benthic vegetation characterized low density. Then, after the first vegetation period, the habitats were spreading, and a primary succession was occurred. To study the distribution of the aquatic vegetation, especially to locate and determine trends and quantity of the growth, an acoustical penetration through the plants was analyzed. Some acoustic beams were reflected from the plant canopy, while other ones reached the bottom surface. The obtained results were processed by an automated aquatic vegetation algorithm (Mielke, 2016), which enabled the assessment of density and height of benthic plants and vegetation mapping.

\section{RESEARCH}

The research were conducted in southern Poland in the following facilities:

- Zator-Podolsze Nowe Aggregate Mine in the town of Zator, where the colonies of protected birds black-crowned night heron birds (Nycticorax nycticorax) nested on the island,

- Dwory Aggregate Mine in the city of Oświęcim, where the aggregates were being extracted in close vicinity to high voltage electricity lines and railway tracks,

- Brzegi Aggregate Mine in the city of Kraków, where the reclamation works were being performed to develop the post-mining area into the water park of Przystań Brzegi,

- Lake of Bagry Wielkie in the city of Kraków where a bathymetric research of a hard-to-reach water area was conducted.

\subsection{Zator-Podolsze Nowe Aggregate Mine}

In 2014, a geodetic inventory of an island, located in the middle of a post mining reservoir, was conducted. The last parts of the deposit in close vicinity to the island remained not exploitated. The island was envi- 


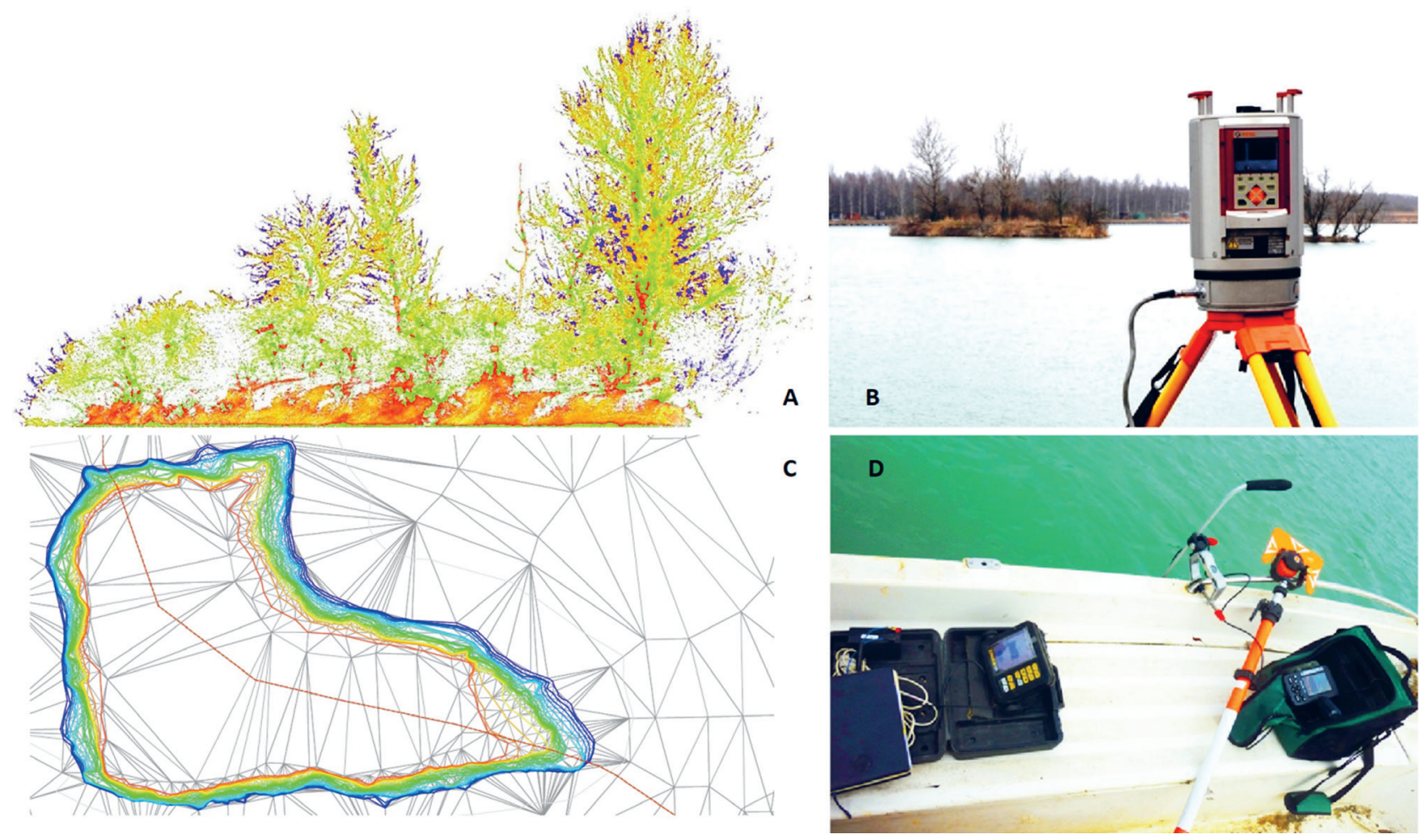

Fig. 1. The research on the island in Zator - Podolsze Nowe Aggregate Mine: A - cloud of points from laser scanning, B - 3D terrestrial laser Scanner Riegl VX 400 during scanning the island, C - digital elevation model of the island, D - standard bathymetry with a regular boat

Rys. 1. Pomiary badawcze wyspy w Kopalni Kruszywa „Zator - Podolsze Nowe”: A - chmura punktów ze skanowania laserowego, B - Skaner Riegl VX 400 w czasie skanowania wyspy, C - numeryczny model terenu wyspy, D - klasyczna batymetria na łodzi

ronmentally protected due to annual colonies of night heron birds (Nycticorax nycticorax). The deposit was planned to be extracted using a dredging machine. The study aimed to assess the stability of the island's edge during the mining works. In order to protect the bird colonies, the research was conducted non-invasively, integrating two measuring methods: 3D laser scanning and bathymetry (fig. 1A-D), (Madusiok and Maciaszek, 2014). The measurement, conducted above the water table, using a 3D terrestrial laser scanner, was very efficient and accurate. Despite all efforts, the underwater observation was ineffective and insufficiently accurate. The measurement of the flooded parts of the island was performed on a regular boat with an echosounder. Unfortunately, the boat could not reach all the edges of the island. The conclusion from the research was that in order to thoroughly measure the flooded slopes of the island, the bathymetric method had to be improved.
Therefore, in the subsequent author's research the improvement of underwater observation was performed, using a remotely controlled device.

\subsection{Dwory Aggregate Mine}

The research in Dwory Aggregate Mine, made with a remotely controlled device, were conducted in the years from 2015 to 2017 . The study aimed to assess the precision and correctness of underwater extraction of aggregates in close vicinity to high voltage electricity lines and railway tracks (fig. 2D). First, to analyze the stability of the slopes during the extraction, depths of the mining water area were measured (fig. 2A). The map of slopes (fig. 2B) based on the depths, was used to indicate steep places of the mining area. Second, to assess the precision of the extraction, analysis of energy of bottom-reflected acoustic beam was per- 


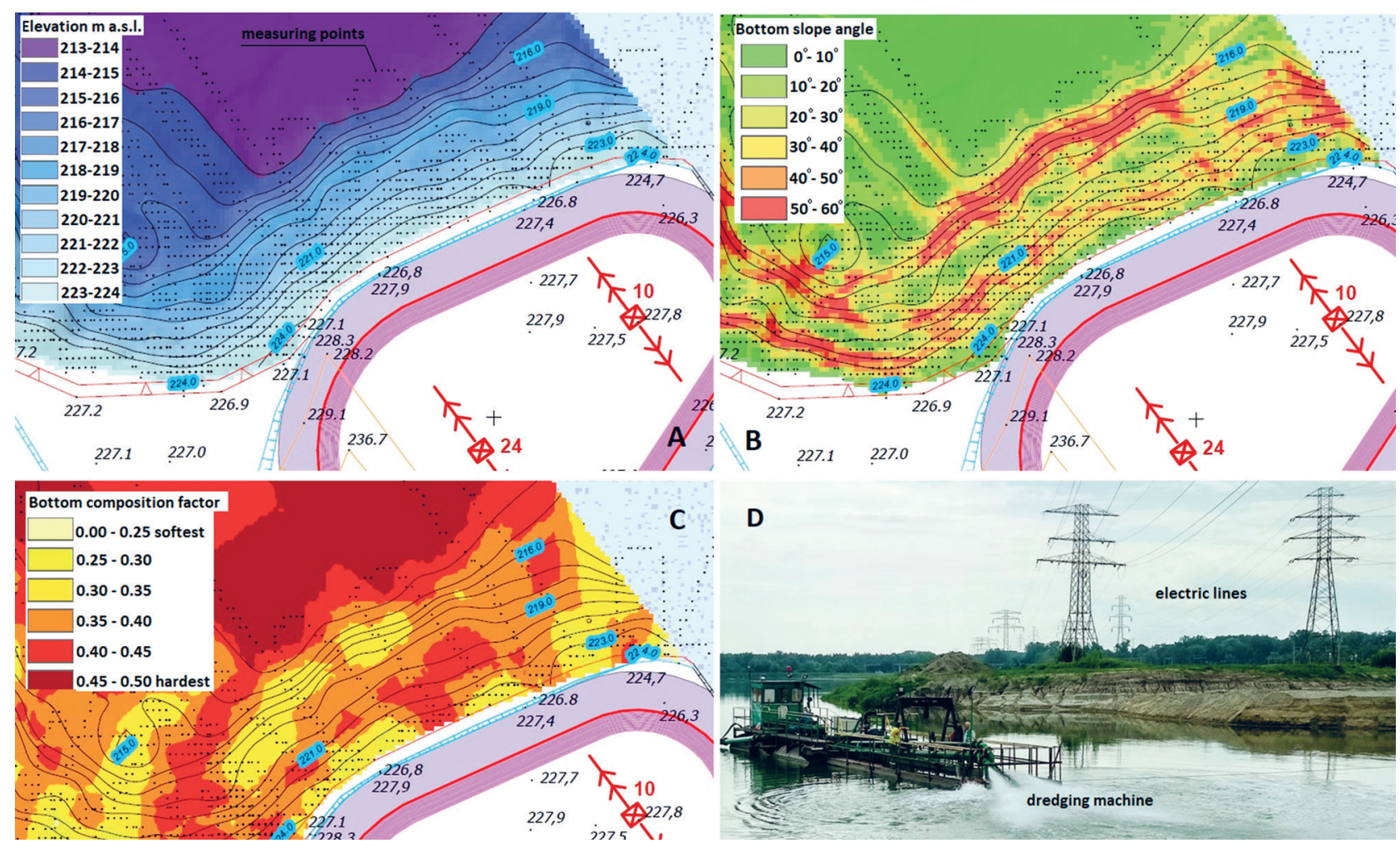

Fig. 2. The research in Dwory Aggregate Mine: A - bathymetric map, B - map of slopes, C - map of bottom composition, $\mathrm{D}$ - remote-controlled measurement in the research area

Rys. 2. Pomiary badawcze w Kopalni Kruszywa „Dwory”: A - mapa batymetryczna, B - mapa nachyleń, C - mapa twardości dna, D - zdalny pomiar batymetryczny w obiekcie badań

formed. Correlation between echo strength and type of the bottom was being observed. Using this physical dependence, the classification of the bottom structure was performed, and then, the identification of the clay material, laying below the aggregate deposit, was conducted. High composition values pointed out extracted areas, and oppositely, low composition values indicated unexploited deposit. The map of the composition of the bottom (fig. 2C) was drawn to illustrate the precision of the extraction. The detailed results, as a part of the author's dissertation (Madusiok, 2017), were published in separate papers (Madusiok, 2015, 2019).

\subsection{Brzegi Aggregate Mine}

The initial research in Brzegi Aggregate Mine in 2016 aimed to support the issue whether the water-recreational direction of reclamation of the post-mining reservoir was reasonable to conduct. For this purpose, a bathymetric measurement, using an unmanned surface vehicle, was conducted. Gradients of underwater slopes and composition of the bottom structure were analyzed. Furthermore, benthic vegetation quantity was determined, especially the trends and quantity of vegetation growth. The above mentioned data were gathered and analyzed together, what supported the decision to invest in recreational direction. Since the 2018, the studied area of the mine - named as Przystań Brzegi (Marina of Shores) - has been used for recreational purposes as a water park (fig. 3). The results of the initial study were published in separate papers (Madusiok, 2016a, 2016b). The research on the facility is still ongoing.

\subsection{Lake Of Bagry Wielkie}

The next author's remote-controlled bathymetric study was conducted in the Krakow's lake of Bagry Wielkie in 2017. The measurement contributed to the R. Gawałkiewicz's research (Gawałkiewicz, 2017a, $2017 b, 2018)$ by complementing the cartographic doc- 


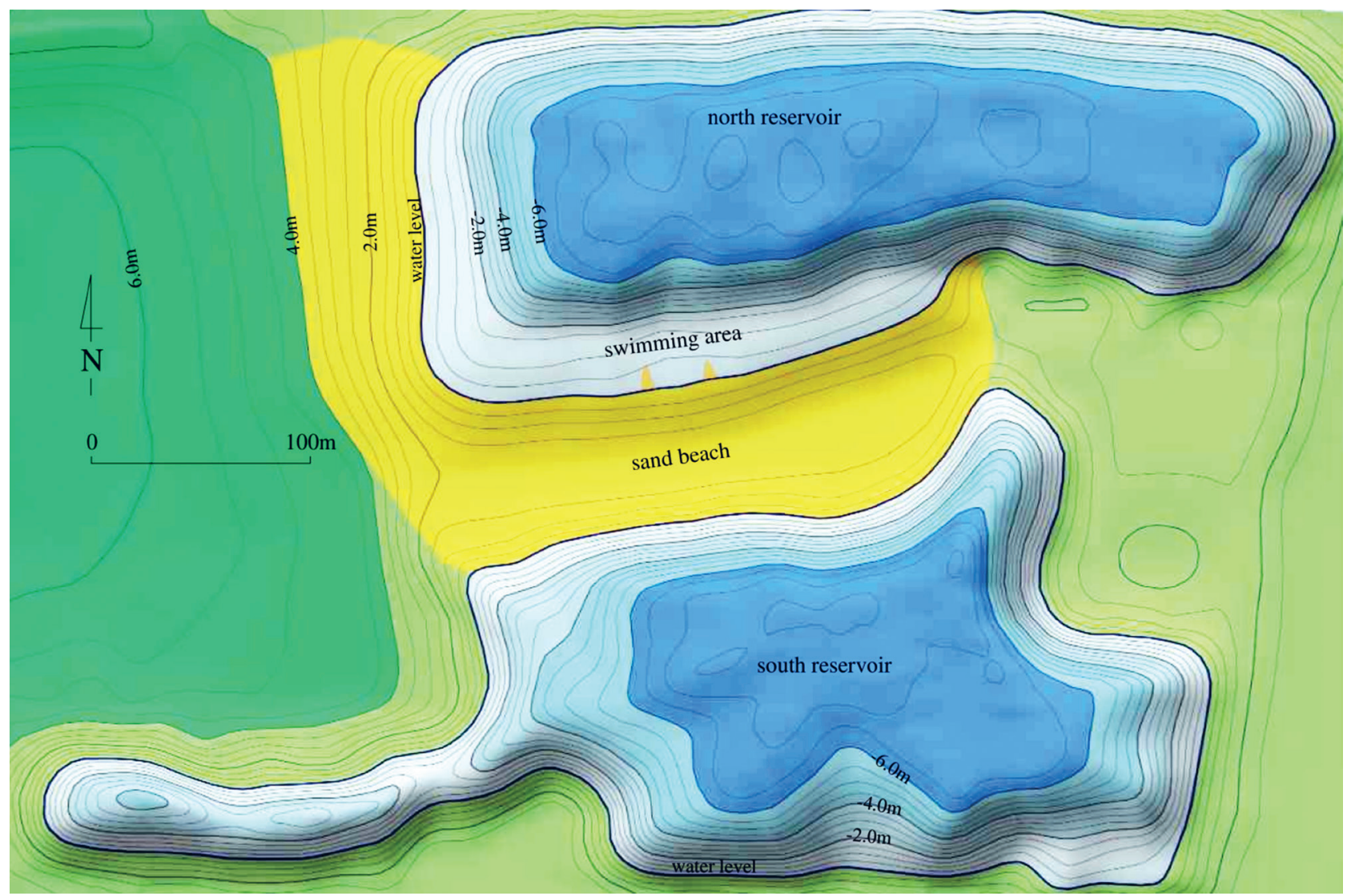

Fig. 3. The map of the water park of Przystań Brzegi in Krakow

Rys. 3. Mapa obiektu rekreacyjnego „Przystań Brzegi” w Krakowie

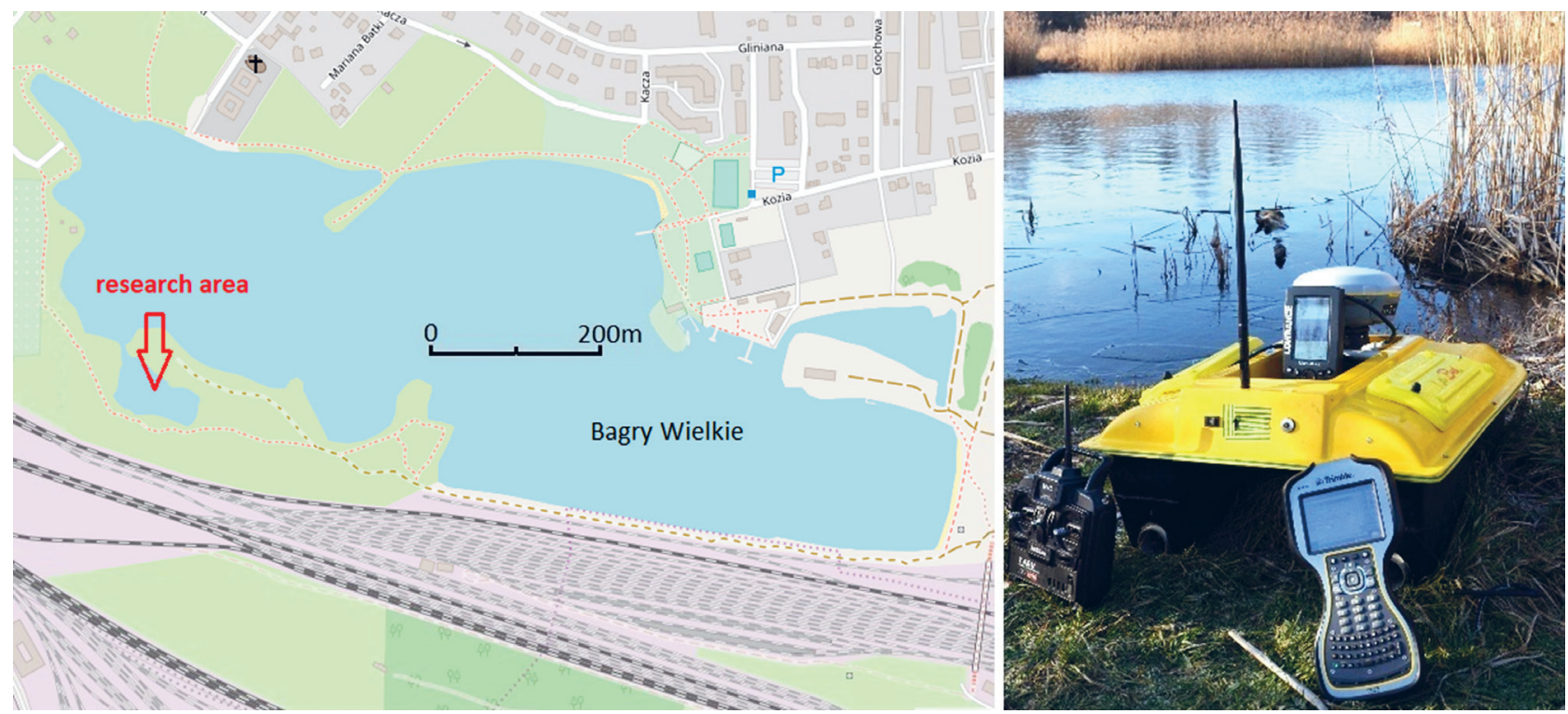

Fig. 4. The Bagry Wielkie study: left - research area, right - applied Smart-Sonar Boat with GPS Trimble (R8s + controller TSC3) Rys. 4. Pomiary badawcze na jeziorze „Bagry Wielkie”: po lewej - rejon badań, po prawej - zastosowany Smart-Sonar-Boat w integracji z GPS Trimble (R8s + kontroler TSC3) 
umentation of the lake. For this purpose, an inventory of a hard-to-reach area of the water body - a small reservoir with an area of about $600 \mathrm{~m}^{2}$ - was performed (fig. 4). The pond was separated from the large lake and was overgrown with aquatic plants, therefore, a standard bathymetry with a regular boat was difficult to implement. Application of a remote-controlled measurement allowed to obtain such parameters of the reservoir as were proposed for the inventory of small water bodies in urban areas (Jakubiak and Panek, 2016). In addition, the type of bottom was analyzed, and, from a biological aspect, the range and intensity of benthic vegetation were indicated. The detailed results of the study were published in separated papers (Gawałkiewicz and Madusiok, 2018a, 2018b).

\section{CONTRIBUTION AND CONCLUSIONS}

The results of the research have contributed to the knowledge about formation of water reservoirs during open-cast mining of aggregates. Application of remotely controlled bathymetry proved the method was practical, economical and accurate. The following goals were achieved:

- assessment of the stability of underwater slopes during the extraction of aggregates in Dwory Aggregate Mine and Zator - Podolsze Nowe Aggregate Mine,

- assessment of the precision of the extraction by recognizing the type of the bottom of the mining water area of Dwory Aggregate Mine,

- verification the possibility of developing the post-mining land for the construction of a water park in Brzegi Aggregate Mine,

- indication of the range and intensity of spreading of benthic plants in the Brzegi facility,

- geodetic and biological inventory of a water area that was difficult to reach in the lake of Bagry Wielkie.

Application of remote-controlled bathymetry in opencast mines enabled obtaining very detailed valuable information about changes occurring in mining water bodies during extraction of aggregates, such as the change of topography, composition or distribution of benthic vegetation. Therefore, the author is planning to continue the bathymetric study in the context of environmental protection. In order to expand the knowledge about the newly created water park of Przystań Brzegi in Kraków, the analysis of the spatial and structural change of the reservoir during the period of the use will be conducted. The analysis will cover the period from the first open in 2018 until the end of 2019. The following issues will be analyzed: stability of underwater slopes, bottom type of reservoir and range and intensity of benthic vegetation.

Achieving the above objectives showed the remote-controlled bathymetric method worked correctly in these conditions. It proved to be a promising technology of measurement in many respects, for example to protect aquatic environment, to manage aquatic resources, or to conduct a safety and precise underwater extraction of natural aggregates.

In the near future, the author plans to investigate the environmental impact of landfills on water environment. The following issues will be analyzed:

- impact of landfilling of construction waste like soil and rubble on environment of post-mining water bodies,

- impact of landfilling of mine waste like coal slate on environment of post-mining water bodies,

- impact of fine sand rejection on aquatic environment during processing of aggregates.

The analysis of above-mentioned impacts would be a valuable contribution to the environmental protection of water resources such as post-mining open reservoirs.

\section{REFERENCES}

Brown, C.J. and Blondel, P. (2009). 'The application of underwater acoustics to seabed habitat mapping', Applied Acoustics. Oxford, England: Elsevier Sci LTD, 70(10)

Bunchuk, A.V and Ivakin, A.N. (1989). 'Energy characteristics of an echo signal from discrete scatterers on the ocean bottom', N.N. Andrew Acoustics Institute, Academy of Science of the USSR. Woodbury, NY USA: Amer Inst. Physics, 35(1), pp. 5-11

Gawałkiewicz, R. (2017a). 'Bagry Lake - volume 1. A bibliographic query of literature and archive data in explaining the evolution of the water', Geoinformatica Polonica, 16, pp. 115-126. Available at: http://www.ejournals.eu/GP/2017/ Vol-16/art/10665/

Gawałkiewicz, R. (2017b). 'Bagry Lake - volume 2. History written in cartographic archives', Geoinformatica Polonica, 16, pp. 127-138., Available at: http://www.ejournals.eu/ $\underline{\mathrm{GP} / 2017 / \text { Vol-16/art/10666/ }}$ 
Gawałkiewicz, R. (2018). 'Application of Integration Measurement Technologies in Inventory of Bagry Water Body', Geomatics and Environmental Engineering, 12, p. 33

Gawałkiewicz, R. and Madusiok, D. (2018a). 'The Bagry Reservoir-part 3. The application of hydro-drone smart-sonar-boat in bathymetric measurements of inaccessible water areas', Geoinformatica Polonica, 17(91), pp. 17-30. Available at: http://www.ejournals.eu/GP/2018/Vol-17/art/12589//

Gawałkiewicz, R. and Madusiok, D. (2018b). 'The Bagry Reservoir-part 4. The application of acoustic sonar lowrence mark-4 in thorough inventory of a difficult-to-access waterbody', Geoinformatica Polonica, 17(91), pp. 31-42. Available at: http://www.ejournals.eu/GP/2018/Vol-17/art/ $12590 /$

Jakubiak, M. and Panek, E. (2016). 'Methodology of surveying small bodies of water in urban areas', Geoinformatica Polonica, 15, pp. 135-142. Available at: http://www.ejournals. eu/GP/2016/Vol-15/art/8408/.

Kloser, R. et al. (2001). 'Remote sensing of seabed types in the Australian South East Fishery; development and application of normal incident acoustic techniques and associated "ground truthing", Marine and Freshwater Research, 52, pp. $475-489$

Kozioł, W. et al. (2013). 'Zastosowanie metod geofizycznych do identyfikacji skał', Górnictwo odkrywkowe, pp. 13-22

Lenda, G. et al. (2015). 'The use of surface interpolation methods for landslides monitoring', KSCE Journal of Civil Engineering, 20, pp. 188-196

Madusiok, D. (2015) 'Badanie wpływu eksploatacji kruszyw naturalnych spod lustra wody w kopalni „Dwory” koło Oświęcimia - Study of the impact of natural aggregates extraction from below the water level in "Dwory" mine near Oświęcim', Bezpieczeństwo Pracy i Ochrona Środowiska w Górnictwie, WUG, pp. 18-23

Madusiok, D. (2016a). 'Analiza możliwości rekultywacji terenów górniczych po eksploatacji kruszywa naturalnego na wybranych przykładach', Miernictwo górnicze i ochrona terenów górniczych w obecnych warunkach wydobycia złóż surowców mineralnych w Polsce; monografia Wojciecha Jaśkowskiego, pp. 101-111

Madusiok, D. (2016b). 'Analysis of the possibilities for reclamation after aggregate exploitation in the Cracow' s quarry of Brzegi by using remote sensing and Geoinformatics', Geoinformatica Polonica, De Gruyter, pp. 113-120. Available at: http://www.ejournals.eu/GP/2016/Vol-15/art/8406

Madusiok, D. (2017). Monitoring geodezyjny ruchów mas ziemnych przy eksploatacji kruszywa spod lustra wody w aspekcie bezpieczeństwa obiektów inżynierskich. AGH University of Science and Technology, Kraków, unpublished doctoral dissertation

Madusiok, D. (2019). 'A bathymetric unmanned surface vessel for effective monitoring of underwater aggregate extraction from the perspective of engineering facilities protection', Archives of Mining Sciences., 64 (2), pp. 375-384, Available at: http://journals.pan.pl/dlibra/publication/128689/edition/112275/content

Madusiok, D. and Maciaszek, J. (2014). 'Monitorowanie metodami skaningu laserowego i sondowania akustycznego wpływu eksploatacji górniczej spod lustra wody na obiekty chronione', Przegląd Górniczy Nr 8/2014, pp. 124-130. Available at: http://www.sitg.pl/przegladgorniczy/pokaz/art1101a20-pdf.html

Mielke, S. (2016). 'Aquatic Vegetation Density Mapping - BioBase 2015 Report', (June)

Ochałek, A. et al. (2018). 'Modeling and Analysis of Integrated Bathymetric and Geodetic Data for Inventory Surveys of Mining Water Reservoirs', E3S Web of Conferences, 35

Orłowski, A. (1984). 'Application of multiple echoes energy measurements for evaluation of sea bottom type', Oceanologia, 19, pp. 61-78

Sessarego, J.-P., Guillermin, R. and Ivakin, A.N. (2008). 'High-Frequency Sound Reflection by Water-Saturated Sediment Interfaces', IEEE Journal of Oceanic Engineering. Piscataway, 33(4), pp. 375-385

Valley, R. (2014). Composition Algorithm Improved! Available at: http://cibiobase.blogspot.com/search/label/hardness 